\title{
Citrobacter werkmanii
}

National Cancer Institute

\section{Source}

National Cancer Institute. Citrobacter werkmanii. NCI Thesaurus. Code C139100.

A species of facultatively anaerobic, gram negative, rod shaped bacteria assigned to the phylum Proteobacteria; this species is motile by peritrichous flagella, it is negative for ornithine decarboxylase activity, and it is positive for growth on malonate. 